\title{
Rhodonellum psychrophilum gen. nov., sp. nov., a novel psychrophilic and alkaliphilic bacterium of the phylum Bacteroidetes isolated from Greenland
}

\author{
Correspondence \\ Peter Stougaard \\ psg@kvl.dk
}

\author{
Mariane Schmidt, ${ }^{1,2} \uparrow$ Anders Priemé $^{2}$ and Peter Stougaard ${ }^{1,3}$ \\ ${ }^{1}$ Bioneer A/S, Kogle Allé 2, Hørsholm, Denmark \\ ${ }^{2}$ Department of Biology, University of Copenhagen, Sølvgade $83 \mathrm{H}$, Copenhagen, Denmark \\ ${ }^{3}$ Department of Ecology, Royal Veterinary and Agricultural University, Thorvaldsensvej 40, \\ DK-1871 Frederiksberg C, Denmark
}

\begin{abstract}
A novel alkaliphilic and psychrophilic bacterium was isolated from the cold and alkaline ikaite tufa columns of the Ikka Fjord in south-west Greenland. According to 16S rRNA gene sequence analysis, strain $\mathrm{GCM} 71^{\top}$ belonged to the family 'Flexibacteraceae' in the phylum Bacteroidetes. Strain $\mathrm{GCM} 71^{\top}$, together with five related isolates from ikaite columns, formed a separate cluster with $86-93 \%$ gene sequence similarity to their closest relative, Belliella baltica. The $G+C$ content of the DNA from strain $\mathrm{GCM} 71^{\top}$ was $43 \cdot 1 \mathrm{~mol} \%$, whereas that of $B$. baltica was reported to be 35 mol\%. DNA-DNA hybridization between strain $\mathrm{GCM} 71^{\top}$ and $B$. baltica was $9.5 \%$. The strain was red pigmented, Gram-negative, strictly aerobic with non-motile, rod-shaped cells. The optimal growth conditions for strain $\mathrm{GCM} 71^{\top}$ were $\mathrm{pH} 9 \cdot 2-10 \cdot 0,5^{\circ} \mathrm{C}$ and $0 \cdot 6 \% \mathrm{NaCl}$. The fatty acid profile of the novel strain was dominated by branched and unsaturated fatty acids (90-97\%), with a high abundance of iso- $\mathrm{C}_{17: 1} \omega 9 c(17 \cdot 5 \%)$, iso- $\mathrm{C}_{17: 0} 3-\mathrm{OH}(17 \cdot 5 \%)$ and summed feature 3 , comprising iso- $\mathrm{C}_{15: 0} 2-\mathrm{OH}$ and/or $\mathrm{C}_{16: 1} \omega 7 c(12 \cdot 6 \%)$. Phylogenetic, chemotaxonomic and physiological characteristics showed that the novel strain could not be affiliated to any known genus. A new genus, Rhodonellum gen. nov., is proposed to accommodate the novel strain. Strain GCM71 ${ }^{\top}$ (=DSM $17998^{\top}=$ LMG $23454^{\top}$ ) is proposed as the type strain of the type species, Rhodonellum psychrophilum sp. nov.
\end{abstract}

\section{Introduction}

Bacteria of the phylum Bacteroidetes often occur in marine and freshwater environments where they may comprise a large fraction of the bacterioplankton community and play an important role in the degradation of organic matter (Cottrell \& Kirchman, 2000; Brettar et al., 2004). In this study, we describe a member of the Bacteroidetes that was isolated from cold and alkaline submarine ikaite columns in the Ikka Fjord, south-west Greenland (Buchardt et al., 1997, 2001; Stockmann et al., 2000). The columns are formed by

tPresent address: Department of Ecology, Royal Veterinary and Agricultural University, Thorvaldsensvej 40, DK-1871 Frederiksberg C, Denmark.

The GenBank/EMBL/DDBJ accession number for the 16S rRNA gene sequence of Rhodonellum psychrophilum sp. nov. $\mathrm{GCM} 71^{\top}$ is DQ112660.

Tables detailing carbon source utilization, the results of API 20NE and API ZYM tests and the fatty acid content of the strains analysed in this study and a graph showing the absorbance spectra of strain GCM71 ${ }^{\top}$ when grown for six weeks with or without light are available as supplementary material in IJSEM Online. the meta-stable cold-water mineral ikaite $\left(\mathrm{CaCO}_{3} \cdot 6 \mathrm{H}_{2} 0\right)$ and stabilized by a microbial biofilm. A rich microbial community of several hundred different bacterial species exists inside the porous ikaite columns (Stougaard et al., 2002; Schmidt et al., 2006). The ikaite columns form a freshwater environment that provides a stable ecological niche for particle-associated bacteria. These bacteria are able to degrade organic matter from the bacteria and higher eukaryotes that inhabit the columns or are trapped in the ikaite during column growth. Members of the phylum Bacteroidetes have been estimated to constitute $7-12 \%$ of the total bacterial diversity inside ikaite columns based on $16 \mathrm{~S}$ rRNA gene fragment clone libraries and culture analysis (Schmidt et al., 2006).

In this study, we isolated five bacterial strains that form a separate lineage within the family 'Flexibacteraceae' of the phylum Bacteroidetes. One of these ikaite isolates, strain GCM $71^{\mathrm{T}}$, was studied in more detail with respect to morphology, growth characteristics, biofilm production, pigmentation, cellular fatty acid content and phylogeny. Our phylogenetic, chemotaxonomic and physiological results lead us to propose a new genus within the phylum 
Bacteroidetes, Rhodonellum gen. nov., with the novel species Rhodonellum psychrophilum sp. nov.

\section{Methods}

Strain $\mathrm{GCM} 71^{\mathrm{T}}$ was isolated from ikaite tufa columns collected from the Ikka Fjord, SW Greenland $\left(61^{\circ} 11^{\prime} \mathrm{N} 48^{\circ}\right.$ $01^{\prime} \mathrm{W}$ ) in 2002. The columns were conserved in $15 \%$ glycerol and kept at $-20^{\circ} \mathrm{C}$. The strain was isolated on agar plates containing R2A medium diluted 10-fold (1/10 R2A) as described by Schmidt et al. (2006). Physiological features were determined using R2 broth medium diluted 10-fold $(1 / 10 \mathrm{R} 2 \mathrm{~B})$ containing the same ingredients as $1 / 10 \mathrm{R} 2 \mathrm{~A}$ except for the agar. The 10-fold diluted R2 broth also contained $1.0 \mathrm{ml} \mathrm{l}^{-1}$ Vogel's trace elements (Hoekstra, 1996) and $1.0 \mathrm{ml} \mathrm{l}^{-1}$ vitamin solution (containing the following ingredients $1^{-1}: 0 \cdot 1 \mathrm{~g}$ thiamine hydrochloride, $0.03 \mathrm{~g}$ vitamin $\mathrm{B}_{12}$ and $0.03 \mathrm{~g}$ D-biotin).

For determination of the optimum $\mathrm{pH}, 1 / 10 \mathrm{R} 2$ broth was adjusted to one of the following $\mathrm{pH}$ values: $6 \cdot 5,7 \cdot 5,8 \cdot 0$, $9 \cdot 2,9 \cdot 5,10 \cdot 0$ or $10 \cdot 7$ using sodium phosphate buffer ( $\mathrm{pH} 6 \cdot 5-8 \cdot 0)$ or sodium carbonate buffer $(\mathrm{pH} 9 \cdot 2-10 \cdot 7)$. Media adjusted to each of the $\mathrm{pH}$ values were filter-sterilized through a $0.22 \mu \mathrm{m}$ pore filter and incubated at different temperatures. The temperatures applied were $0,5,10,15,22$, 30,37 and $45^{\circ} \mathrm{C}$. The medium used for carbon utilization analysis was $1 / 10 \mathrm{R} 2 \mathrm{~B}$ adjusted to $\mathrm{pH} 10$, except it was not supplemented with glucose and soluble starch. Even though this medium still contains low levels of yeast extract and peptone, no growth was observed when no other carbon sources were added and therefore this medium was used for the carbon utilization experiment. The individual carbon sources were added to a final concentration of $20 \mathrm{mM}$ (see Supplementary Table S1 in IJSEM Online) and the inoculated cultures were incubated at $10^{\circ} \mathrm{C}$. Growth requirements were also tested with the API 20NE and API ZYM (bioMérieux) commercial systems. The manufacturer's guidelines were followed with the following exceptions: cells from a $25 \mathrm{ml}$ culture were collected and used for the assay, the AUX medium was adjusted to $\mathrm{pH} 9 \cdot 2$ using a $1 \mathrm{M}$ carbonate/bicarbonate buffer and the assay was incubated at $10{ }^{\circ} \mathrm{C}$. The API $20 \mathrm{NE}$ test was read after 24 and $48 \mathrm{~h}$ as instructed, while the API ZYM was read after 5 days.

Salinity tolerance and requirement were determined in $1 / 10$ R2B containing $0,0 \cdot 1,0 \cdot 3,0 \cdot 6,1 \cdot 0,1 \cdot 5,3 \cdot 0$ and $6 \cdot 0 \%(\mathrm{w} / \mathrm{v})$ $\mathrm{NaCl}$ with $\mathrm{pH}$ adjusted to $10 \cdot 0$ at $10^{\circ} \mathrm{C}$. All growth experiments were performed with six replicates and growth in broth cultures was measured as $\mathrm{OD}_{600}$ in flat-bottomed 96-well microtitre plates using a ELX808 RIU reader (Biotek).

The novel strains were tested for a number of characteristics using standard procedures such as Gram staining, oxidase test (Microbiology Bactident oxidase-strips), catalase test $\left(\mathrm{H}_{2} \mathrm{O}_{2}\right)$ and cell size and morphology (phase-contrast microscopy and scanning electron microscopy).
Photosynthetic growth was determined on full strength $\mathrm{R} 2 \mathrm{~A}$ (aerobic) and in R2 broth (anaerobic, atmosphere: $20 \% \mathrm{CO}_{2}, 80 \% \mathrm{~N}_{2}$ ) in glass jars sealed with rubber stoppers. Inoculated agar plates and glass jars were incubated at $5{ }^{\circ} \mathrm{C}$ and illuminated at $20-40 \mu \mathrm{E} \mathrm{m}^{-2} \mathrm{~s}^{-1}$. Control cultures were grown in darkness at $5^{\circ} \mathrm{C}$.

Identification of biofilm production was performed using a modified version of the methods described by O'Toole \& Kolter (1998), Prigent-Combaret et al. (2001) and Dorel et al. (1999). Colonies isolated on R2A media were precultured in $\mathrm{R} 2$ broth before inoculation in flat-bottomed 96-well microtitre plates with $200 \mu \mathrm{l}$ per well. Plates were sealed with Parafilm and incubated at $5{ }^{\circ} \mathrm{C}$ with 75 r.p.m. shaking for 4 days. To correlate biofilm formation to planktonic cell growth in each well, the planktonic cell fraction was transferred to a new microtitre plate and $\mathrm{OD}_{600}$ was measured in a Wallac-Victor ${ }^{2} 1420$ Multilabel Counter. Biofilm formation by attached cells was analysed with crystal violet staining as previously reported by O’Toole \& Kolter (1998). Crystal violet bound to biofilm was measured as absorbance at $\mathrm{A}_{600}$ using the Wallac-Victor ${ }^{2} 1420$ Multilabel Counter. Absorbance measurements obtained were related to the $\mathrm{OD}_{600}$ of the planktonic cell fraction.

DNA was extracted from the strains using the DNeasy tissue kit (Qiagen) following the manufacturer's instructions for Gram-negative bacteria. 16S rRNA gene fragment amplification was carried out using primers $27 \mathrm{~F}$ and $1492 \mathrm{R}$, while primers 27F, 519R, 532F, 907R, 926F and 1492R (Lane, 1991) were used in the sequencing reaction. Sequence analysis was performed using an automatic DNA sequencer (ABI PRISM 310 Genetic Analyzer; Applied Biosystems), applying the BigDye Terminator Cycle sequencing kit (Applied Biosystems) following the manufacturer's protocols. Alignment of sequences was carried out using the CLUSTAL $w$ algorithm from the EMBL-EBI homepage (http://www.ebi.ac.uk/clustalw) and BioEdit 7.0.4.1 software (Hall, 1999). A phylogenetic tree was created by neighbour-joining analysis (bootstrap $=100)$ using TREECON 1.3b software (Van de Peer \& De Wachter, 1994).

DNA-DNA hybridization and the DNA $\mathrm{G}+\mathrm{C}$ content of strain GCM71 ${ }^{\mathrm{T}}$ were analysed at DSMZ, Braunschweig, Germany. DNA was isolated using a French pressure cell (Thermo Spectronic) and purified by chromatography on hydroxyapatite as described by Cashion et al. (1977). DNADNA hybridization was carried out as described by De Ley et al. (1970), incorporating the modifications described by Huß et al. (1983), using a Cary 100 Bio UV/VIS-spectrophotometer equipped with a Peltier-thermostatted $6 \times 6$ multicell changer and a temperature controller with an in situ temperature probe (Varian). The DNA G $+\mathrm{C}$ content was determined by HPLC and the ratio was calculated from the ratio of deoxyguanosine $(\mathrm{dG})$ and thymidine $(\mathrm{dT})$ according to the method of Mesbah et al. (1989).

For fatty acid analysis, the novel strain was grown on fullstrength $\mathrm{R} 2 \mathrm{~A}, \mathrm{pH} 10$ at $5^{\circ} \mathrm{C}$. Fatty acid extraction was 
performed using standard procedures for GC fatty acid analysis as described by Sasser (1990) and fatty acid analysis was performed as described by Mansfeld-Giese et al. (2002).

For pigment analysis, the novel strain was grown on fullstrength $\mathrm{R} 2 \mathrm{~A}, \mathrm{pH} 10$ at $5{ }^{\circ} \mathrm{C}$. Spectral reflectance features of individual bacterial colonies were measured with a fibreoptic spectrometer (USB2000; Ocean Optics) operated with a PC running the data acquisition software, OOIBase32 (Ocean Optics; USA). The flat-cut end of a multimode optical fibre (fused silica, $600 \mu \mathrm{m}$ diameter, numerical aperture $0 \cdot 22$ ) was fixed in a hypodermic needle on a syringe. This was then mounted on a micromanipulator. The other end of the fibre was connected to the spectrometer via a standard SMA connector. A Petri dish containing the bacterial strain was illuminated vertically from above with a fibre-optic halogen lamp with the heat filter removed and equipped with a collimating lens. The Petri dish was placed on top of a white reflectance standard. Before each measurement, the fibre probe was carefully positioned at the surface of the agar plate at an angle of about $45^{\circ}$ relative to the vertical. After initial recording of spectra in darkness, a reference spectrum, $R_{0}(\lambda)$, of the reflectance from agar without bacteria was recorded. Subsequent measurements of spectral reflectance from bacterial colonies, $R_{b}(\lambda)$, were expressed as quasi-absorbance spectra, $\mathrm{A}(\lambda)=\log _{10}\left[\left(\mathrm{R}_{0}(\lambda) /\right.\right.$ $\left.\mathrm{R}_{\mathrm{b}}(\lambda)\right]$.

\section{Results and discussion}

Cells of strain GCM $71^{\mathrm{T}}$ were Gram-negative, oval to straight rods of $0 \cdot 8-3 \mu \mathrm{m}$ in length and $0 \cdot 7-1 \mu \mathrm{m}$ in width. Motility was not observed by phase-contrast microscopy. Cells were observed to multiply by binary division and occasionally chains of up to eight cells were observed. Colonies grown in darkness were circular $(0.5-3.0 \mathrm{~mm}$ in diameter $)$, smooth and bright red. When grown under light conditions, colonies were smaller $(0 \cdot 1-1 \cdot 0 \mathrm{~mm}$ in diameter), irregular and transparent to light red.
Strain GCM71 ${ }^{\mathrm{T}}$ was strictly aerobic, oxidase-negative and catalase-positive. It grew in the range $0-22^{\circ} \mathrm{C}$, while the optimal growth temperature was $5-10{ }^{\circ} \mathrm{C}$ (Fig. 1). Strain GCM $71^{\mathrm{T}}$ had a growth range between $\mathrm{pH} 7 \cdot 5$ and $\mathrm{pH} 10 \cdot 7$. The broadest $\mathrm{pH}$ range $(\mathrm{pH} 7 \cdot 5-10 \cdot 7)$ was observed at the optimal growth temperature, i.e. at $5-10{ }^{\circ} \mathrm{C}$. Above and below the optimal growth temperature, the $\mathrm{pH}$ range was narrower $(\mathrm{pH} 9 \cdot 2-10 \cdot 0)$. Strain $\mathrm{GCM} 71^{\mathrm{T}}$ grew best in the range of $0-1.5 \% \mathrm{NaCl}(\mathrm{w} / \mathrm{v})$, with an optimum around $0.6 \% \mathrm{NaCl}$ (Table 1). No growth was detected above $3 \%$ $\mathrm{NaCl}$. The strain may need $\mathrm{Na}^{+}$as an adaptation to living in an alkaline environment (Krulwich et al., 1997), whereas $\mathrm{Cl}^{-}$seems not to be essential. In the R2-based carbonassimilation assay, several compounds were utilized as sole carbon source when grown chemotropically (aerobic/dark) (see Supplementary Table S1 in IJSEM Online). Strain GCM71 ${ }^{\mathrm{T}}$ showed activity in the API $20 \mathrm{NE}$ system with positive results for $\beta$-glucosidase and $\beta$-galactosidase activities and for the assimilation of glucose, mannose, $\mathrm{N}$ acetylglucosamine and maltose. Furthermore, strain GCM71 ${ }^{\mathrm{T}}$ showed good activity in the API ZYM assay, where only tests for lipase (C14), $\beta$-glucuronidase and $\alpha$ fucosidase were negative (see Supplementary Table S2 in IJSEM Online).

Strain $\mathrm{GCM} 71^{\mathrm{T}}$ was not capable of anaerobic growth, either chemo- nor phototropically. When grown at $5{ }^{\circ} \mathrm{C}$, strain GCM $71^{\mathrm{T}}$ showed weak biofilm formation during a 4-day growth period.

Approximately 1400 bases of $16 \mathrm{~S}$ rRNA gene sequences were determined from strain $G C M 71^{\mathrm{T}}$. The $16 \mathrm{~S}$ rRNA gene sequences showed that the strain was affiliated to the family 'Flexibacteraceae' of the phylum Bacteroidetes. The closest recognized relative to strain GCM $71^{\mathrm{T}}$ was Belliella baltica (Brettar et al., 2004) (Fig. 2). Furthermore, strain GCM71 ${ }^{\mathrm{T}}$ forms a cluster with the previously reported, but as yet uncharacterized, ikaite isolates ikaite c9 (GenBank accession no. AJ431335) (Stougaard et al., 2002), GCM63

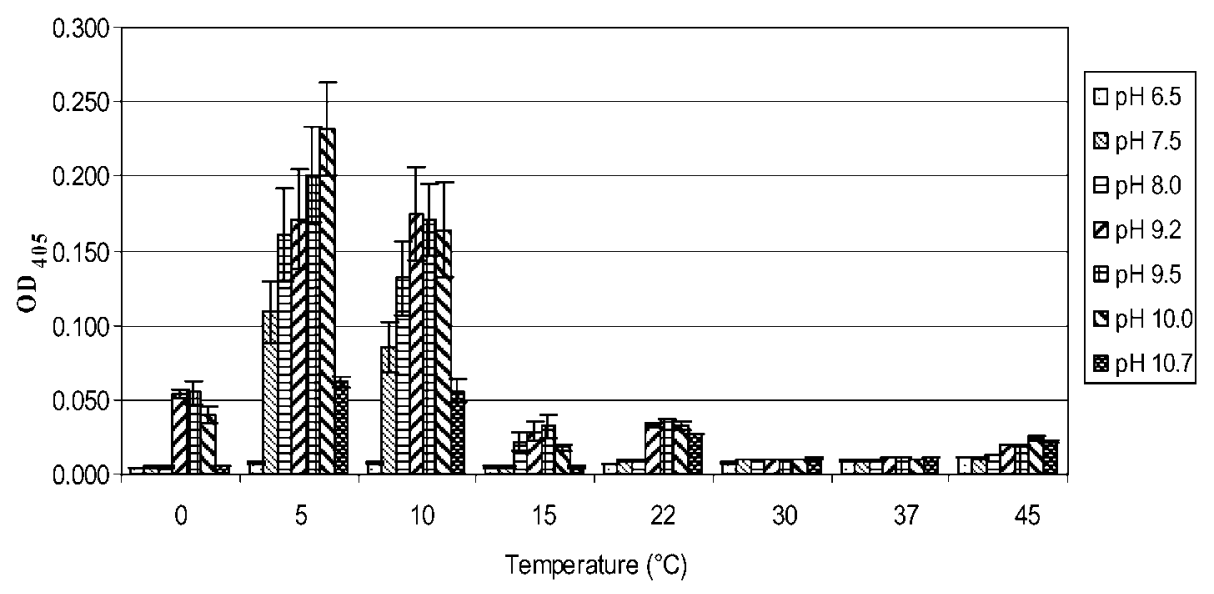

Fig. 1. Optimal growth temperature and $\mathrm{pH}$ for strain $\mathrm{GCM} 71^{\top}$. Standard error $(n=6)$ is indicated on each bar. 
Table 1. Differential characteristics of Rhodonellum psychrophilum sp. nov. GCM71 ${ }^{\top}$ and Belliella baltica BA134 ${ }^{\top}$

Data for B. baltica are from Brettar et al., 2004. ND, Not determined.

\begin{tabular}{|c|c|c|}
\hline Characteristic & GCM71 $^{\mathrm{T}}$ & Belliella baltica $\mathrm{BA} 134^{\mathrm{T}}$ \\
\hline Cell morphology & Rods, straight & Rods, straight \\
\hline Cell size $(\mu \mathrm{m})$ & $0 \cdot 7-1 \times 0 \cdot 8-3$ & $0 \cdot 3-0 \cdot 4 \times 1 \cdot 5-3 \cdot 0$ \\
\hline Colony colour & Pink/red & Pink/orange \\
\hline DNA G $+C$ content $(\mathrm{mol} \%)$ & $43 \cdot 1$ & $35 \cdot 3-35 \cdot 5$ \\
\hline \multicolumn{3}{|l|}{ Pigments: } \\
\hline Carotenoids & Yes & Yes \\
\hline \multicolumn{3}{|l|}{ Salinity (\%): } \\
\hline Growth range & $0-3 \cdot 0$ & $0-6$ \\
\hline Optimum & $0-0 \cdot 6$ & $0-3 \cdot 4$ \\
\hline \multicolumn{3}{|l|}{ Temperature $\left({ }^{\circ} \mathrm{C}\right)$ : } \\
\hline Growth range & $0-22$ & $4-37$ \\
\hline Optimum & 5 & $25-30$ \\
\hline \multicolumn{3}{|l|}{ pH: } \\
\hline Growth range & $7 \cdot 5-10 \cdot 7$ & $6-10$ \\
\hline Optimum & $9 \cdot 2-10 \cdot 0$ & ND \\
\hline Catalase activity & + & + \\
\hline Cytochrome $c$ oxidase activity & - & + \\
\hline
\end{tabular}

(DQ028355) (Schmidt et al., 2006) and three additional ikaite isolates GCM68, GCM69 and GCM70 (GenBank accession nos DQ112662, DQ112661 and DQ112663, respectively). Sequences in this cluster shared an $86-93 \%$ gene sequence similarity to their closest relative, $B$. baltica. The unidentified Hailaer soda lake bacterium Z3 (GenBank accession no. AF275712) shared $86-91 \%$ gene sequence similarity with the ikaite isolates $\left(91 \%\right.$ to strain $\left.\mathrm{GCM} 71^{\mathrm{T}}\right)$, whereas bacteria of the genera Cyclobacterium and Algoriphagus only showed $90 \%$ gene sequence similarity to strain GCM71 ${ }^{\mathrm{T}}$. No species of the genera Cyclobacterium and Algoriphagus are known to be alkaliphilic. However Algoriphagus antarcticus from Lake Reid, Antarctica, is reported to be a psychrophilic bacterium (Van Trappen et al., 2004).
DNA-DNA hybridization was $2 \cdot 6-9 \cdot 5 \%$ between strain GCM71 ${ }^{\mathrm{T}}$ and B. baltica. One other isolate from ikaite columns, GCM70, showed between $66 \cdot 5$ and $69 \cdot 6 \%$ DNADNA hybridization with strain GCM7 ${ }^{\mathrm{T}}$. This indicates that these isolates may represent two different species, since the threshold value to separate two species is $70 \%$ (Wayne et al., 1987). Growth physiological data support this fact, but other data, from fatty acid profiles, API tests and 16S rRNA gene sequence similarity, indicate that these two strains may belong to the same species.

The DNA G + C content of strain GCM71 ${ }^{\mathrm{T}}$ was $43 \cdot 1 \mathrm{~mol} \%$, whereas those of $B$. baltica and Cyclobacterium marinum have been reported to be $35 \cdot 3-35 \cdot 5 \mathrm{~mol} \%$ and 34-38 mol\%, respectively (Brettar et al., 2004).

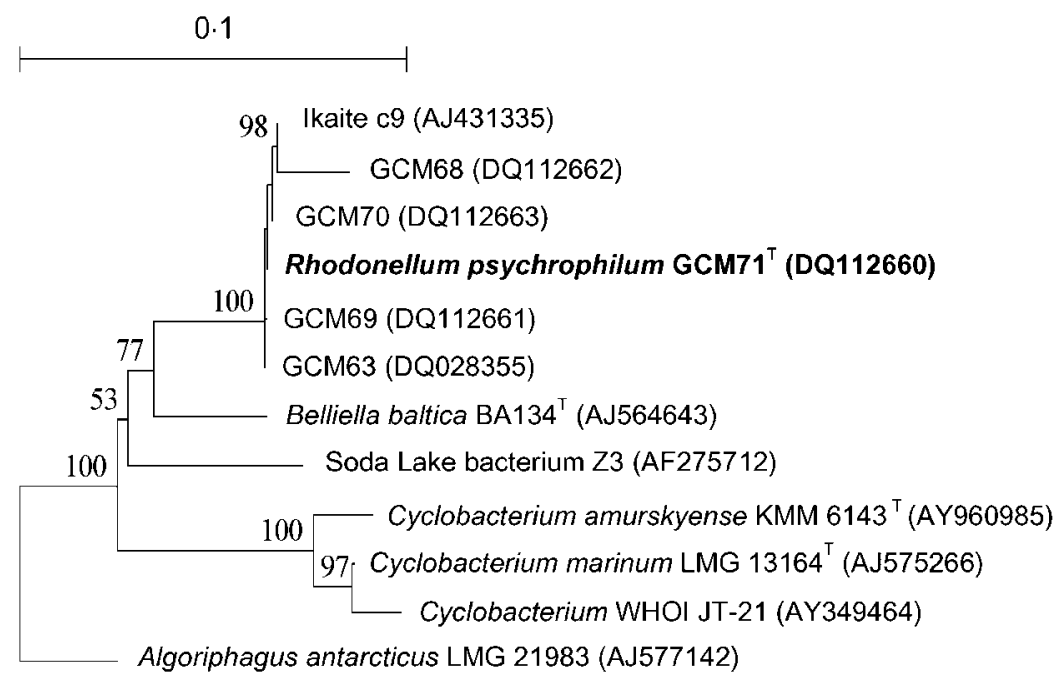

Fig. 2. Phylogenetic dendrogram based on comparison of $16 \mathrm{~S}$ rRNA gene sequences from strains isolated from ikaite and some of their closest phylogenetic relatives. The tree was created by neighbour-joining analysis. Bootstrap $(n=100)$ values below 50 are not shown. Algoriphagus antarcticus was used as the outgroup. Bar, $0 \cdot 1$ substitutions per nucleotide position. 
Predominant fatty acids of strain $\mathrm{GCM} 71^{\mathrm{T}}$ were iso- $\mathrm{C}_{15: 1}$ $\mathrm{G}(6 \cdot 3 \%)$, iso- $\mathrm{C}_{15: 0}(7 \cdot 6 \%)$, iso- $\mathrm{C}_{16: 1} \mathrm{H} \quad(7 \cdot 3 \%)$, iso- $\mathrm{C}_{17: 1} \omega 9 c(17 \cdot 5 \%), \mathrm{C}_{17: 1} \omega 6 c(6 \cdot 8 \%)$, iso- $\mathrm{C}_{17: 0} 3-\mathrm{OH}$ $(17 \cdot 5 \%)$ and summed feature 3 , comprising $\mathrm{C}_{16: 1} \omega 7 \mathrm{c}$ and/ or iso- $\mathrm{C}_{15: 0} 2-\mathrm{OH}(12.6 \%)$, and summed feature 4 , comprising $\mathrm{C}_{14: 0} 2-\mathrm{OH}$ and/or iso- $\mathrm{C}_{15: 0} 2-\mathrm{OH}(6 \cdot 5 \%)$, which could not be distinguished by the method applied (see Supplementary Table S3 in IJSEM Online). The cellular fatty acid content of the strain was dominated by branched and unsaturated fatty acids which make up around $90 \%$ of the total fatty acids if summed feature 4 is not included and around $97 \%$ of the total fatty acids if summed feature 4 is included. Summed feature 3 was included because it consists of a branched and/or an unsaturated fatty acid. The large amount of branched and unsaturated fatty acids in the cell walls is a characteristic adaptation of both alkaliphilic and psychrophilic bacteria as these fatty acids increase membrane fluidity and hence increase cellular activity and transport processes at low temperatures and elevated $\mathrm{pH}$ (Nichols et al., 2002; Feller \& Gerday, 2003; Furusawa \& Koyama, 2004). When the fatty acid profile of strain GCM $71^{\mathrm{T}}$ is compared with that of the phylogenetically closest relative, $B$. baltica, both are dominated by iso- $\mathrm{C}_{15: 0}$, iso- $\mathrm{C}_{17: 1} \omega 9 c, \mathrm{C}_{17: 1} \omega 6 c$ and summed feature $3\left(\mathrm{C}_{16: 1} \omega 7 c\right.$ and/or iso- $\left.\mathrm{C}_{15: 0} 2-\mathrm{OH}\right)$. The most remarkable difference is the lower content of $\mathrm{C}_{15}$ fatty acids together with the higher amount of iso- $\mathrm{C}_{17: 1} \omega 9 c$ and iso- $\mathrm{C}_{17: 0} 3-\mathrm{OH}$ in strain GCM $71^{\mathrm{T}}$ as compared with $B$. baltica.

Strain GCM71 ${ }^{\mathrm{T}}$ was not capable of phototrophic growth under anaerobic conditions. Under aerobic conditions, colonies subjected to light $\left(20-40 \mu \mathrm{E} \mathrm{m}^{-2} \mathrm{~s}^{-1}\right)$ were small $(0 \cdot 1-0.5 \mathrm{~mm}$ in diameter), irregular and light red to transparent. Colonies grown aerobically under dark conditions were larger $(0 \cdot 5-3 \cdot 0 \mathrm{~mm}$ in diameter), more regular in shape and bright red in colour. An absorbance spectrum for both strains showed a broad peak with maximum absorbance at $489 \mathrm{~nm}$ with two shoulder peaks at 460 and $517 \mathrm{~nm}$, which suggest the presence of carotenoids (Supplementary Fig. S1, IJSEM Online). The closest relative, B. baltica, showed a similar carotenoid absorption spectrum with absorption peaks at 450, 475 and $505 \mathrm{~nm}$ (Brettar et al., 2004). The absorbance at these wavelengths was $3 \cdot 5-4$ times higher in isolates grown under dark conditions than in isolates grown in the light. Furthermore, both strains had four smaller peaks above $670 \mathrm{~nm}$. The isolates grown under dark conditions had peaks at 694, 745, 815 and $907 \mathrm{~nm}$, while isolates grown in the light had peaks at $676,727,788$ and $853 \mathrm{~nm}$.

A novel alkaliphilic and psychrophilic bacterium, strain GCM $71^{\mathrm{T}}$, was isolated from the permanently alkaline and cold ikaite columns in the Ikka Fjord in south-west Greenland. The strain is phylogenetically related to bacteria of the phylum Bacteroidetes with B. baltica as the closest relative. DNA-DNA hybridization analysis and DNA G + C content determination, as well as differences in cell morphology, growth physiology and fatty acid profiles, support the notion that strain $\mathrm{GCM} 71^{\mathrm{T}}$ is a novel species belonging to a new genus. We propose a new genus, Rhodonellum gen. nov., comprising the species Rhodonellum psychrophilum sp. nov. Strain GCM71 $1^{\mathrm{T}}$ is the type strain of R. psychrophilum sp. nov.

\section{Description of Rhodonellum gen. nov.}

Rhodonellum (Rho.do.nell.um. Gr. neut. n. rhodon a rose; L. neut. dim. ending -ellum; N.L. neut. n. Rhodonellum a small rose, referring to the red colour of the colonies).

Cells are Gram-negative, rod-shaped, oxidase-negative and catalase-positive. Growth is heterotrophic, aerobic and chemoheterotrophic. Predominant fatty acids are iso$\mathrm{C}_{17: 1} \omega 9 c$, iso- $\mathrm{C}_{17: 0} 3-\mathrm{OH}(12 \cdot 5-18 \cdot 5 \%)$ and summed feature 3. Cells contain red pigment in the form of carotenoids. Optimal growth occurs above $\mathrm{pH} 9 . \mathrm{NaCl}$ is not required for growth, but growth is enhanced by the presence of up to $0.6 \% \mathrm{NaCl}$. The genus Rhodonellum belongs to the class 'Sphingobacteria' and the family 'Flexibacteraceae'. The type species is Rhodonellum psychrophilum.

\section{Description of Rhodonellum psychrophilum sp. nov.}

Rhodonellum psychrophilum (psy.chro'phi.lum. Gr. adj. psychros cold; Gr. adj. philos loving; N.L. neut. adj. psychrophilum cold-loving).

Colonies are smooth, circular and red due to the presence of carotenoids when grown under low light intensities. Colonies are white to light red when grown at light intensities of $20-40 \mu \mathrm{E} \mathrm{m}^{-2} \mathrm{~s}^{-1}$. Cells are Gram-negative, rod-shaped, $0 \cdot 8-3 \mu \mathrm{m}$ in length and $0 \cdot 7-1 \mu \mathrm{m}$ in width and are oxidase-negative and catalase-positive. Growth occurs at temperatures from 0 to $22^{\circ} \mathrm{C}$, with an optimum at around $5^{\circ} \mathrm{C}$. Growth occurs from $\mathrm{pH} 7 \cdot 5$ to above $\mathrm{pH} 10 \cdot 7$, with an optimum at $\mathrm{pH} 9 \cdot 2-10 \cdot 0$. At optimal growth temperature, the range of tolerated $\mathrm{pH}$ is largest, while below and above the optimal growth temperature, a narrower $\mathrm{pH}$ range is tolerated. $\mathrm{NaCl}$ is not required for growth, but up to $3 \%$ $(\mathrm{w} / \mathrm{v}) \mathrm{NaCl}$ is tolerated. Optimal growth occurs around $0.6 \%(\mathrm{w} / \mathrm{v}) \mathrm{NaCl}$. Strains are able to use a wide spectrum of carbon sources such as galactose, lactose, maltose, mannose, starch, glycerol and sorbitol. DNA G + C content of the type strain is $44 \cdot 2 \mathrm{~mol} \%$.

The type strain is $\mathrm{GCM} 71^{\mathrm{T}}\left(=\mathrm{DSM} \quad 17998^{\mathrm{T}}=\mathrm{LMG}\right.$ $\left.23454^{\mathrm{T}}\right)$.

\section{Acknowledgements}

We thank Karin Vestberg for excellent technical skills, Carsten Aarup for biofilm analysis and John Larsen for analysis of fatty acids. Michael Kühl is acknowledged for helping with the pigment analysis and stimulating discussions. Referring to the Convention on Biological Diversity, we thank the Greenland Home Rule for permission to 
sample ikaite columns from the Ikka Fjord, SW Greenland. This work was partly funded by the Villum Kann Rasmussen Foundation and the Danish Agency for Trade and Industry (M.S. and P. S.).

\section{References}

Brettar, I., Christen, R. \& Höfle, M. G. (2004). Belliella baltica gen. nov., sp. nov., a novel marine bacterium of the CytophagaFlavobacterium-Bacteroides group isolated from surface water of the central Baltic Sea. Int J Syst Evol Microbiol 54, 65-70.

Buchardt, B., Seaman, P., Stockmann, G. \& 9 other authors (1997). Submarine columns of ikaite tufa. Nature 390, 129-130.

Buchardt, B., Israelson, C., Seaman, P. \& Stockmann, G. (2001). Ikaite tufa towers in Ikka Fjord, Southwest Greenland: their formation by mixing of seawater and alkaline spring water. J Sedimentary Res 71, 176-189.

Cashion, P., Hodler-Franklin, M. A., McCully, J. \& Franklin, M. (1977). A rapid method for base ratio determination of bacterial DNA. Anal Biochem 81, 461-466.

Cottrell, M. T. \& Kirchman, D. L. (2000). Community composition of marine bacterioplankton determined by $16 \mathrm{~S}$ rRNA gene clone libraries and fluorescence in situ hybridization. Appl Environ Microbiol 66, 5116-5122.

De Ley, J., Cattoir, H. \& Reynaerts, A. (1970). The quantitative measurement of DNA hybridization from renaturation rates. Eur J Biochem 12, 133-142.

Dorel, C., Vidal, O., Prigent-Combaret, C., Vallet, I. \& Lejeune, P. (1999). Involvement of the Cpx signal transduction pathway of $E$. coli in biofilm formation. FEMS Microbiol Lett 178, 169-175.

Feller, G. \& Gerday, C. (2003). Psychrophilic enzymes: hot topics in cold adaptation. Nat Rev Microbiol 1, 200-208.

Furusawa, H. \& Koyama, N. (2004). Effect of fatty acids on the membrane potential of an alkaliphilic Bacillus. Curr Microbiol 48, 196-198.

Hall, T. A. (1999). BioEdit: a user-friendly biological sequence alignment editor and analysis program for Windows 95/98/NT. Nucleic Acids Symp Ser 41, 95-98.

Hoekstra, R. F. (1996). Horizontal transmission in fungal populations. In Fungal Genetics: Principles and Practice, pp. 337-348. Edited by C. J. Bos. Marcel Dekker, New York.

Huß, V. A. R., Festl, H. \& Schleifer, K. H. (1983). Studies on the spectrophotometric determination of DNA hybridization from renaturation rates. Syst Appl Microbiol 4, 184-192.

Krulwich, T. A., Ito, M., Gilmour, R. \& Guffanti, A. A. (1997). Mechanisms of cytoplasmic $\mathrm{pH}$ regulation in alkaliphilic strains of Bacillus. Extremophiles 1, 163-169.
Lane, D. J. (1991). 16S/23S rRNA sequencing. In Nucleic Acid Techniques in Bacterial Systematics, pp. 115-175. Edited by E. Stackebrandt \& M. Goodfellow. New York: Wiley.

Mansfeld-Giese, K., Larsen, J. \& Bødker, L. (2002). Bacterial populations associated with mycelium of the arbuscular mycorrhizal fungus Glomus intraradices. FEMS Microbiol Ecol 41, 133-140.

Mesbah, M., Premachandran, U. \& Whitman, W. (1989). Precise measurement of the $\mathrm{G}+\mathrm{C}$ content of deoxyribonucleic acid by highperformance liquid chromatography. Int J Syst Bacteriol 39, 159-167.

Nichols, D. S., Sanderson, K., Buia, A. \& 7 other authors (2002). Bioprospecting and biotechnology in Antarctica. In The Antarctic: Past, Present and Future (Antarctic CRC Research Report no. 28), pp. 85-103. Edited by J. Jabour-Green \& M. Haward. Hobart, Australia.

O'Toole, G. A. \& Kolter, R. (1998). Initiation of biofilm formation in Pseudomonas fluorescens WCS365 proceeds via multiple, convergent signalling pathways: a genetic analysis. Mol Microbiol 28, 449-461.

Prigent-Combaret, C., Brombacher, E., Vidal, O., Ambert, A., Lejeune, P., Landini, P. \& Dorel, C. (2001). Complex regulatory network controls initial adhesion and biofilm formation in Escherichia coli via regulation of the $c s g D$ gene. J Bacteriol 183, 7213-7223.

Sasser, M. (1990). Identification of bacteria through fatty acid analysis. In Methods in Phytobacteriology, pp. 199-203. Edited by Z. Klement, K. Rudolph \& D. C. Sands. Budapest: Akademiai Kaido.

Schmidt, M., Priemé, A. \& Stougaard, P. (2006). High microbial diversity in permanently cold and alkaline ikaite columns from Greenland. Extremophiles (in press). doi: 10.1007/s00792-006-0529-9

Stockmann, G., Buchardt, B. \& Kristiansen, A. (2000). The submarine 'ikaite column garden' in Ikka Fjord, SW Greenland. Northern Sci Network Newsl 26/27.

Stougaard, P., Jørgensen, F., Johnsen, M. G. \& Hansen, O. C. (2002). Microbial diversity in ikaite tufa columns: an alkaline, cold ecological niche in Greenland. Environ Microbiol 4, 487-493.

Van de Peer, Y. \& De Wachter, R. (1994). TREECON for Windows: a software package for the construction and drawing of evolutionary trees for the Microsoft Windows environment. Comput Appl Biosci 10, 569-570.

Van Trappen, S., Vandecandelaere, I., Mergaert, J. \& Swings, J. (2004). Algoriphagus antarcticus sp. nov., a novel psychrophile from microbial mats in Antarctic lakes. Int J Syst Evol Microbiol 54, 1969-1973.

Wayne, L. G., Brenner, D. J., Colwell, R. R. \& 9 other authors (1987). International Committee on Systematic Bacteriology. Report of the ad hoc committee on reconciliation of approaches to bacterial systematics. Int J Syst Bacteriol 37, 463-464. 